\title{
Sustainable Affordable Housing Strategies for Solving Low- Income Earners Housing Challenges in Nigeria
}

\author{
DANIA, SUNDAY FESTUS ${ }^{1,2}$, NOR HASANAH ABDUL SHUKOR LIM ${ }^{1}$, AIN NAADIA MAZLAN ${ }^{1}$ \\ ${ }^{1}$ Department of Structures and Materials, UNIVERSITI TEKNOLOGI MALAYSIA. \\ ${ }^{2}$ Department of Building Technology, AUCHI POLYTECHNIC, AUCHI, NIGERIA. \\ E-mail: sunday1986@graduate.utm.my; sunny4alldanias@auchipoly.edu.ng
}

\begin{abstract}
Globally, several studies have affirmed that the population of those who are displaced with respect to housing is on the rise. Developing nations in the continent of Africa to include Nigeria are reportedly not spared of this development. Similarly, the low-income earners have been reported as the worst hit of this global menace. Shanty dwellings, squatter settlements and informal settlements have similarly been reported to be homes to low-income earners who constitute over $90 \%$ of the population of Nigeria. This study therefore presented sustainable affordable housing strategies as an emerging concept through which low-income earners housing challenges in Nigeria can be eliminated. The study relied on a systematic review of literature to arrive at its findings. Findings from the study revealed that sustainable affordable housing strategies through which Nigerian low-income earners housing challenges can be addressed can best be explored from the social, economic, environmental, institutional and technological components of sustainable affordable housing. The study calls on the government, stakeholders, policy makers as well as private developers to adopt sustainable affordable housing strategies for low-income housing provision in Nigeria. The study's outcome will contribute to existing body of knowledge in that it will provide useful information with respect to low-income housing provision and equally re-direct research interest on low-income housing in Nigeria and other developing nations.
\end{abstract}

Keywords: Low-Income Earners Housing Challenges; Sustainable Affordable Housing Strategies, Nigeria.

JEL Classification: $0,01,018$ 


\section{Introduction}

Virtually all human activities on planet earth revolves around a house. Thus, housing can no longer be seen as just a roof over ones head but instead, it has become a component at the centre of man's evolvement and development [1]. World over, housing has also been adjudged as one of the indices through which the welfare of humans can be measured $[2,3]$. Similarly, housing has equally been reported as been potent in the areas of employment generation as well as the development of the economy of nations $[4,5,6]$. However, [7] submitted that only decent houses are capable of delivering the above mentioned benefits. The study added that indecent dwellings are of no benefit to its users and occupiers in all ramifications and spheres. Overall, [8] submitted that decent dwellings are necessary for all.

Housing in spite of its benefits as highlighted in the preceding paragraph has been reported to be in gross undersupply across the globe. To this end, the [9] reported that globally, the population of those who are homeless because they reside in shanty towns and informal settlements stands at 863 million and fast approaching a billion. The [9] similarly affirmed that over $61.7 \%$ of the population of Africa are homeless. In Nigeria, a recent study conducted by [10] affirmed that between 17-20 million Nigerians are homeless. Furthermore, an abundance of research evidences have affirmed that the lowincome earners are chief among the sufferers of these housing shortages [11, 12, 13, 14, 15, 16]. The studies further reported that the incidence of housing shortages and inadequacies is far worse for lowincome earners in developing nations like Nigeria.

Talking about Nigeria, studies has confirmed that the low-income earners who constitute over $90 \%$ of its population are displaced with respect to housing as a result of the inability of the low-income earners to afford the cost (rental, building or outright purchase) of housing occasioned by the increasing costs of building materials, deficient policies of housing, cost of land for housing development, increased interests and inflation rates amongst others $[17,18,19,20,21,22,23,24,25]$. Past government efforts targeted at improving the situation of housing for the lower income citizens in Nigeria have been reported to have equally failed as a result of poor implementation, poor funding, inefficient strategies amongst others $[24,26]$. In addition, studies have equally affirmed that the effect of the most recent housing policy of Nigeria (NHP 2012) which was premised on the need to provide all Nigerians with affordable homes on a sustained basis and targeted at addressing low-income earners affordability challenges with respect to housing is yet to be felt because of the absence of an operational strategy to drive its operation $[18,26,27,28]$.

Nevertheless, there are growing concerns that addressing all affordability concerns of the lowincome earners with respect to housing as set out in the 2012 housing policy of Nigeria is not a guarantee for successful housing for the low-income earners. Similarly, [29, 30, 31, 32] affirmed that focusing on affordability concerns alone without recourse to social wellbeing and sustainability issues in relation to housing for the low-income earners will mean housing without the basic infrastructures and services for the low-income earners. Furthermore, emerging trends in relation to low-income housing have advocated for the need to jointly address sustainability and affordability concerns since low-income earners housing needs have progressed beyond price affordability to other sustainability issues [33, 34, 11,12].

Consequently, it has become crucial to integrate sustainability dimensions into low-income affordable housing as encouraged by emerging studies. When the dimensions of sustainability are integrated into affordable housing in low income housing developments, the concept of sustainable affordable housing is initiated. Housing for the low-income earners that is sustainable and at the same time affordable as reported by $[11,35,36]$ therefore is housing that fulfils the needs of housing of the low-income earners whilst conserving their capacities to meet other needs of the future. It entails the process of achieving an enhanced quality of life for the low-income earners through the systematic use of available resources thus ensuring a continuous system of social progress and at the same time sustaining the environment as well as ensuring the steady growth of the economy [37]. 
However, sustainable affordable housing for low-income earners as a concept has been reported not to have been explored both in research and housing developments in Nigeria and many other developing nations irrespective of its potentials in addressing low-income earners housing challenges $[11,38]$. This study therefore, in response to calls for the need to advance a strategy to drive the Nigerian 2012 housing policy as well as emerging research interests on the need to pursue low-income earners housing provision from the perspective of integrating sustainability dimensions into affordable housing if successful housing is envisaged for the low-income earners, is aimed at highlighting sustainable affordable housing strategies through which the perennial low-income earners housing crisis in Nigeria as well as other developing nations with similar characteristics can be addressed. The study is therefore structured thus: Introduction, Methodology, Overview of sustainable affordable housing for the low-income in Nigeria and conclusions.

\section{Methodology}

The study considered the systematic review of literature as the most suitable strategy to achieve its aim. This is largely due to the fact that previous studies of $[39,40]$ as cited by [41] have affirmed that a systematic review stands as an essential scientific tool in social science researches that can be adopted to elicit results and as well base a decision on a research involving large publications. Similarly, in carrying out the systematic review, the five (5) step data gathering procedure (development of the questions of the research, identification of related researches, evaluation of the worth and content of the identified researches, aggregation and profiling of the research results and finally, explanation and comprehension of the results of the researches) as advanced by [40] and [42] became necessary.

The procedure which commenced with a comprehensive search and review of articles, conference proceedings, peer-reviewed journal publications and books between March and October 2020 was carried out using Scopus online database as the principal literature source and supported by Google Scholar online database. Scopus online database was adopted as the principal literature source because of its wide range of journal coverage involving special features in keywords searching as well as citation analysis [43] as cited by [41]. Similarly, words such as sustainable affordable housing, sustainable affordable housing in Nigeria, Housing provision for the low-income earners in Nigeria, Housing provision in Nigeria, low-income earners housing challenges in Nigeria were keyed into the search arena and $722,23,41,147,15$ articles were retrieved respectively. Overall, the searches conducted in the two databases generated 948 articles.

The article titles and abstracts were then reviewed for the purpose of identifying those whose full texts will be reviewed and used in the study. This led to the selection of 384 articles. The 384 articles were then rated using the rating system of 3 for very relevant, 2 not so relevant and 1 for not relevant. Articles with rating 3 were eventually reviewed and used for the study as a result of their objectives and the extent of their relevance to the study. The data obtained from the systematic review process were processed using the thematic content analysis strategy. This involved the discussion of the sustainable affordable housing components along the social, economic, environmental, institutional and technological themes as identified from the systematic review. Based on the themes, sustainable affordable housing strategies through which low-income housing challenges can be addressed in Nigeria was presented.

\section{Sustainable Affordable Housing}

Sustainable affordable housing as a concept emerged from of the integration of the aspects of sustainable housing into affordable housing [11]. Sustainable housing as it were was said to have originated from the concept of sustainable development. Similarly, sustainable development as a concept was reported to have emerged from the report titled "Our Common Future" of the United Nations World Commission on Environment and Development (WCED) [44]. The WCED report which is popularly referred to as the Brundtland Report however defined sustainable development as that type of development that is geared towards securing today's generation needs whilst conserving the 
capacities of coming generations to meeting their own needs when they arise [44]. Addressing the needs of today's generation as well as securing the capability of addressing the needs of future generations as contained in the WCED report principally borders on the need to achieve a social, environment and economic balance in the pursuance of developments $[45,46]$.

Furthermore, $[47,48,49,50]$ studies reported that sustainable housing ideology which emerged through an advocacy drive premised on environmental friendliness in the UK further sought to propagate the need to achieve a social, economic and environmental balance in housing as it is the case with sustainable development. With a view to defining the meaning of sustainable housing, the UN-Habitat (2012) submitted that sustainable housing just like sustainable development is largely concerned with the location of the house, the design and methods of construction adopted, the integration of the house with economic, cultural, social and the environmental fabric of communities. Furthermore, $[11,16,51]$ studies submitted that the broad focus of sustainable housing is on the need to achieve as well as secure a balance socially, environmentally and economically in relation to housing.

Affordable housing on the other hand has largely been viewed with respect to cost of housing in relation to income of households [52]. The concept was further seen as the ability of households to secure decent dwellings without having to go through neck breaking financial stresses [53, 54]. Similarly, $[55,56,57]$ advanced the $30 \%$ benchmark as the qualifying percentages that housing costs must meet for it to be seen as affordable to households particularly the low-income earners. However, insinuations have emerged that tying affordable housing to cost alone as well as specifying the percentage that it should cost with respect to low-income households are been advanced without recourse to the composition of households, the quality of the house as well as neighbourhood features, the size of the house, the location of the house amongst others. To this end, [58, 59] submitted that for affordable housing goals to be realised, then broader issues in addition to cost should be deployed into its assessment and analysis.

Furthermore, emerging studies across the globe have sued for the need to emphasize housing adequacy issues in affordable housing development for the lower income citizens [8, 31, 60,61]. In addition, $[34,58,62,63,64,65,66,67]$ studies noted that sustainable affordable housing is initiated when housing adequacy issues otherwise referred to as sustainability dimensions are jointly addressed alongside the income focus of affordable housing. $[16,37,68]$ further added that it is crucial for both affordability and sustainability issues to be jointly addressed if successful communities and housing are envisaged for the low-income citizens.

Integrating the concerns of sustainable and affordable housing together to arrive at the concept of sustainable affordable housing is housing type with the potentials of addressing the low-income earners housing challenges globally $[33,16,68,69,70,71,72,73,74,75]$. The studies added that the concept can lead to an increased supply of infrastructures and amenities to the low-income earners as well as an $80 \%$ reduction in the consumption of energy in buildings. Similarly, $[76,77]$ studies asserted that with sustainable affordable housing, some form of balance can be achieved between nature and human activities without adversely impacting social, economic as well as environmental systems for future generations.

However, Nigeria and other countries in the continent of Africa as well as other developing climes have been reported not to have embraced the concept of sustainable affordable housing in lowincome housing provision. $[38,78]$ studies affirmed that researches as well as developments focusing on the concept of sustainable affordable housing for lower income citizens are non-existing and where they exist, they are at their emerging state in Nigeria and many other developing nations. Also, studies have equally affirmed that even in most developed climes where the awareness of the concept of sustainable affordable housing has reportedly been on, the concepts are most often used interchangeably thus suggesting that there still exist an obvious lack of understanding of the concepts as well as its components $[11,78]$.

With a view to defining the scope and components through which sustainable affordable housing can be better understood, [79] harped on the need for the inclusion of technology to the existing 
focuses of sustainable affordable housing as a result of the impact that building and housing developments have on the environment. [8] corroborating [79] study opined that integrating sustainability dimensions into affordable housing may not be successful if expertise in technology is ignored. [33] equally argued that there is need to consider the institutional/regulatory input alongside the established economic, social and environmental focus of sustainable affordable housing if realistic results are envisaged. Therefore, in the light of the foregoing, sustainable affordable housing focus in this paper shall be accessed through the social, economic, environmental, institutional and technological components as posited by $[33,8,68,79]$. Similarly, the strategies of sustainable affordable housing through which low-income earners housing challenges can be addressed in this study shall be discussed under the social, economic, environmental, institutional and technological themes.

\section{Sustainable Affordable Housing Strategies for Solving Low-Income Earners Housing Challenges in Nigeria}

The table 1 below provides a list of sustainable affordable housing strategies through which lowincome earners challenges can be addressed in Nigeria and other developing nations. Based on the findings from reviewed literature, five (5) principal components of sustainable affordable housing were identified. They are social, economic, environmental, institutional and technological components.

Through these components, the strategies were discussed.

Table 1: Sustainable affordable housing strategies

\begin{tabular}{|c|c|c|}
\hline Strategies & Promotion of social capital, social inclusion and social cohesion & Authors \\
\hline Social & Retrofitting of aged buildings & {$[80]$} \\
\hline & Promotion of high density development/diversity in housing & {$[33]$} \\
\hline Economic & Provision of incentives to developers & {$[82]$} \\
\hline & Development of a robust financial market & {$[83,84]$} \\
\hline Environment & Provision of housing subsidies/incentives to households & {$[85]$} \\
\hline & Conservation of energy in buildings & {$[86,87]$} \\
\hline & Development and utilization of local resources & {$[88,89]$} \\
\hline Institutional & Efficient land use and planning & {$[90,91]$} \\
\hline & Control and reduction of wastes and natural disasters & {$[92,93]$} \\
\hline & Promotion of the use of reusable, renewable and recyclable materials & {$[83]$} \\
\hline & Formulation of sound housing policies & {$[79]$} \\
\hline & Transparent/robust procurement process & {$[94]$} \\
\hline & Decentralization of authority and responsibility & {$[95]$} \\
\hline
\end{tabular}

Source: Authors compilation from systematic review

\subsection{Social strategies of sustainable affordable housing}

The incidence of income segregation has been reported as one of the challenges standing against the low-income earners access to adequate housing globally $[99,100]$. Nigerian low-income earners have been reported to be displaced with respect to housing as a result of their low financial status [18, $17,20,19,23,25]$. The low-income earners as a result of their low financial status are 
confined/restricted to city/urban outskirts where infrastructural facilities are absent thus making their housing conditions more like slums. Similarly, low financial status creates an environment where income segregation strives. However, [80] reported that one of the social strategies of sustainable affordable housing is that it seeks to reduce/eliminate income/wealth segregation through the promotion of social capital, inclusion and cohesion. Social cohesion brings about a sense of belonging, social solidarity and emphasises on the need to interact within families and communities. Similarly, social capital brings about support and co-operation among societies thus leading to the actualization of safety and belongingness needs of households. Additionally, social inclusion brings about the unhindered access of households and families to resources thus leading to the efficient participation and involvement of the households in economic, political and social activities within the community. All of these put together can foster the relationship as well as inter relationship between the lowincome, middle income and the high income households thereby reducing drastically, the incidence of income/wealth segregation.

Furthermore, the incidence of poor maintenance culture and abandoned management of public facilities has also been reported as a challenge limiting the low-income earners access to adequate housing globally $[101,102]$. Poor maintenance and the abandonment of public facilities has become a common practice in Nigeria and many other African countries [103]. Poor maintenance has led to an increased proportion of aged and deficient infrastructures all around the world [81]. These aged and deficient infrastructures are unfortunately home to low-income earners. Arguments have however been advanced with respect to how to make these aged and deficient infrastructures more suitable and functional. To this end, $[81,104]$ noted that retrofitting of aged infrastructures to sustainable affordable standards is cheaper and more beneficial compared to outright demolition and reconstruction. The studies added that through the retrofitting of aged infrastructures which is one of the social strategies of sustainable affordable housing, the facades of the infrastructures are retained, more employments are created while an almost $80 \%$ reduction in energy usage can be achieved thereby boosting the low-income earners housing conditions.

Additionally, the incidence of inadequate infrastructural development/supply has also been identified as a challenge confronting low-income housing in most African countries [71, 105]. Most African countries have been reported as developing nations and home to most low-income earners across the globe hence, infrastructural development is in limited supply. However, through the practice of high density housing development and the diversity of housing types which are social strategies of sustainable affordable housing as reported by [33], low-income earners housing challenge of insufficient supply of infrastructure can be addressed. Similarly, by practicing high density housing development as well as diversity of housing types, the low-income enjoys proximity to the available infrastructures as well as spend less on other non-housing costs. This strategy equally leads to mixed housing development and by extension equally reduces income segregation.

\subsection{Economic strategies of sustainable affordable housing}

Most countries in the world have recognised and empowered the private sector with the responsibility of the provision of housing while the government of these countries simply act as an enabler and promoter. Against this backdrop, [83] reported that the development of housing in the world and most African countries is hampered by the unavailability of incentives to private investors and developers. Private sector players are profit oriented hence, most of their outputs are unaffordable to the low-income. The burden that the cost of housing comes with are transferred by the developers/investors to the households through rent or outright purchase thus making the lowincome unable to access existing units [106]. However, [82] noted the strategy of providing investors/developers with incentives (loans, tax rebates etc.) which happens to be one of the economic strategies of sustainable affordable housing if adopted by stakeholders, can help address the challenge and by extension, grant the low-income greater access to housing. Similarly, incentives in the form of flexibility in design can equally go a long way to motivate the investors/developers there by leading to lower housing prices for the low-income [107]. 
Furthermore, low-income housing in Nigeria has been reportedly trammelled as a result of inflation, high interest rates and high cost of building materials $[99,24,53]$. These challenges have further made housing unaffordable to the low-income. However, with the availability of a stable financial/housing market been an economic strategy of sustainable affordable housing, the issues of high interest rates, inflation rates as well as high cost of building materials can be addressed [103, 95]. The uncertainty of the market system has led to the loss of interest by investors and developers thus leaving only a few investors left in the housing market. Therefore, the stabilization of the market will increase the confidence level of private investors/developers. With a stable market, there is the assurance of the involvement of more private investors/developers. This will help to control inflation rates as well as prices of commodities. Overall, a stable financial/housing market shall certainly empower the lowincome and grant them more access to housing.

Additionally, the low financial status of low-income earners in Nigerian has also been reported as one of the reasons why housing is in limited supply to the low-income [108]. Prices of existing housing units in Nigeria are outside the reach of the low-income earners as a result of their poor/weak financial status. However, the provision of housing subsidies in the form of loans and mortgages at lower interest rates to low-income households been another economic strategy of sustainable affordable housing can help to address the challenge [109]. Similarly, [64] noted that the economic focus of sustainable affordable housing is to provide households with incentives in the form of reduced transportation as well as other non-housing costs. Overall, the provision of financial incentives to lower income households shall cushion the economic power of the low-income thereby resulting into better housing for the low-income.

\subsection{Environmental strategies of sustainable affordable housing}

Globally, buildings consume close to $40 \%$ of energy thus making it the highest consumer of energy [110]. The building and construction industry contributes nearly one third of Global Greenhouse Gas (GHG) Emissions [111]. This has led to serious discomfort both in and within the building. Regrettably, the low-income finds itself in the middle of this discomfort and even suffer more discomfort as a result of the inadequate situation of their dwellings. Against this backdrop, [112] sued for the need for the adoption of energy efficiency strategies in buildings. Similarly, the environmental strategy of sustainable affordable housing seeks to achieve energy conservation in buildings through the encouragement and promotion of the use of energy efficient lighting systems, solar heating technologies, energy efficient heating systems, ventilation and air condition systems, installation of water efficient appliances, rain water harvesting technologies as well as the improvements of the housing envelops generally [87, 113]. These strategies no doubt can lead to an increase in the housing cost which is already unaffordable to the low-income but however, with an incentive driven housing market, these costs can be, managed [82]. Similarly, [104] submitted that close to $80 \%$ reduction in energy consumption can be achieved in buildings that adopt the above mentioned strategies. This will certainly lead to more comfort in the environment both indoors and outdoors for the low-income earners.

Furthermore, the non-utilization of local resources irrespective of their abundance in Nigeria and most African countries has equally been reported as one of the reasons why housing is not in sufficient supply to the low-income [21]. Moreover, imported building materials come at a cost that is obviously outside the reach of the low-income. However, the promotion and use of local resources presents itself as part of the environmental strategies of sustainable affordable housing $[88,89]$. Sustainable affordable housing through its environmental strategy, harps on the need to promote the usage of local resources in the form of tax reliefs and incentives to entrepreneurs who are interested in investing along that line. Development and usage of local resources in building will lead to a drastic decline in the price of imported building materials and by extension, the entire cost of housing units thus making it affordable to the low-income. It will also lead to the creation of jobs.

Similarly, land for housing development has also been reported as one of the challenges confronting the low-income earners access to housing in Nigeria $[27,53]$. Available lands according to the authors 
are been given out at prices that are outside the reach of the low-income. Moreover, high cost of land is a major obstacle to the development of sustainable affordable housing [114]. However, inefficient land use planning could be responsible for this development [96]. As a way out, the efficient use and planning of land which is another environmental strategy of sustainable affordable housing could be employed to address the challenge $[90,91]$. In doing this, the government, community and individual land owners are encouraged to give out lands to developers as equity. In turn, the developers upon completion allocates some housing units to the providers of the land. Where the land was provided by the government, the allocated housing units can in turn be given as low-income housing. This will lead to mixed income housing development and effective land use planning [33].

Furthermore, the incidences of natural disaster and high rate of internal displacement have also been reported as been contributory reasons why the low-income earners are displaced with respect to housing in Nigeria [27]. The low-income in Nigeria have become victims of environmental disasters of all kinds as a result of the location of their dwellings. However, this ugly development/trend can be averted. Of the numerous environmental strategies of sustainable affordable housing, one of it seeks to address the occurrences of disasters through the conduct of environmental and geological assessments before the commencement of actual development [92]. Through the assessments, immediate and future harms are known and steps taken to mitigate their occurrence and effect. The cost of the assessment together with the cost of the project may appear high but however, the underlying benefit that the assessment portends makes the undertaking worthwhile. Similarly, the low-income will suffer no additional financial burden arising from the conduct of the environmental assessments since private investors/developers are going to be motivated through incentives.

\subsection{Institutional strategies of sustainable affordable housing}

The low-income in Nigeria has been reported to be displaced with respect to housing as a result of over politicization of the system, the lack of political will on the part of the political gladiators, corruption as well as the limited involvement of the private sector [115, 27, 26, 53]. The studies further reported that developed mass houses that were hitherto meant for the low-income were at the long run allocated to high and middle income earners who had no need for them but for the fact that they are allies of the stakeholders in the Nigerian housing sector. The high and middle income earners do later re-sell the housing units and equally put out some for rent. In all, the low-income earners are always schemed out of housing opportunities in Nigeria. However, a key institutional strategy of sustainable affordable housing seeks to empower the private sector in the delivery of mass housing as recommended in the enabling approach $[116,117,83]$. The studies added that with the involvement of the private sector, issues like corruption, politicization that have held the housing sector aback can be addressed.

Furthermore, the housing policy instrument of Nigeria has reportedly been adjudged to be unable to deliver housing opportunities to the low-income as a result of poor operational framework as well as deficient implementation strategies $[18,24,23]$. Similarly, the studies further asserted that the effect of the most current housing policy of Nigeria is yet to be felt by those in the lower income bracket. However, it is the responsibility of the government to formulate the right housing policies [22]. Similarly, [94] submitted that one of the institutional strategies of sustainable affordable housing harps on the need to develop, review and update housing policies from time to time in line with existing realities. The continuous review as well as updating of housing policies in accordance with existing realities as recommended by sustainable affordable housing practices will no doubt go a long way to addressing low-income earners housing needs. A sound housing policy is an all-encompassing housing document in that it addresses issues related to land for housing, building materials, housing types, all income groups and many more [96].

Additionally, government mass housing development has also been plagued by secrecy, favouritism and incompetence. In Nigeria for example, $[24,26,118,119]$ are of the opinion that the incidences of social menace to include the desire for more profit, the employment of unqualified persons to man housing departments and agencies, unreasonable professional charges amongst others has held the 
delivery of housing to the low-income down for decades. Furthermore, the studies added that the process leading to the award of contracts are marred with all sort of irregularities. However, with sustainable affordable housing practice, all of these anomalies can be addressed. A key institutional strategy of sustainable affordable housing is centred on a procurement process that is effective and transparent [95]. With a transparent and effective procurement process in place, the incidences of favouritism, incompetence and undue desire for profit can be addressed. This will certainly help in the transfer of government housing projects to those it was intended for (the low-income). Additionally, a lot of cost will be saved when a transparent and effective procurement process is in place the study added.

Furthermore, the time allotted to developmental approval has also hindered the adequate supply of housing to the low-income in Nigeria [33, 26, 120]. The studies added the bureaucratic process as well as the undue delay has led to cost and time overruns. However, with the practice of sustainable affordable housing, these challenges can as well be addressed. An institutional strategy of sustainable affordable housing harps on the need to decentralize planning and approval authorities as well as responsibilities to local authorities $[96,97]$. The studies added that by decentralizing and shifting approvals to local authorities, a lot of time can be saved. This would serve as an incentive to developers and overall, more housing units can be delivered to the low-income.

\subsection{Technological strategies of sustainable affordable housing}

The incidences of inadequate technological knowhow, wrong comprehension of sustainable technological processes, uncertainty about technological performances as well as the ever changing nature of technology has again been reported as challenges limiting the development of sustainable affordable housing in developing nations [121, 122]. Moreover, the continuous escalation of the prices of building materials coupled with the degradation of the environment due to over exploitation occasioned by developmental activities equally calls for the need to develop and upgrade local resources to sustainable standards. Similarly, upgrading of local resources to sustainable standards requires technology [79]. As a way forward, a key technological strategy of sustainable affordable housing harps on the need to promote technological innovation [98]. This will bring about the needed awareness. Furthermore, another technological strategy of sustainable affordable housing focuses on the promotion of the use of reusable, renewable and recyclable materials [79]. Through this, the environment shall be further conserved and the incidences of disaster can be further managed.

Similarly, the pace at which technology is advancing posses a treat to previous skills [8]. As a result, developers spend more resources to hire and bring in experts in other to cope with technological changes. This development has further chocked the low-income as a result of the cost of the eventual product. However, with the promotion, growth and development of local and rudimentary technologies which is a technological strategy of sustainable affordable housing, many of these challenges can be addressed $[79,128]$. By promoting the development and growth of local technology, the scarcity of skilled labour can be addressed while direct employments can as well be created. Also, the huge finances spent on hiring as well as bring in experts will be saved. As a result, housing prices shall be drastically reduced thereby increasing the low-income earners access to housing.

\section{Conclusions}

Giving the rate at which low-income housing is worsening in Nigeria, the need to consider sustainability dimensions in the development of affordable housing becomes more imperative. Till date, this study found that there is no evidence that sustainability dimensions have been integrated into affordable housing development for the low-income earners in Nigeria. This has to be addressed if meaningful results are envisaged with respect to low-income housing. Similarly, sustainable affordable housing for the low-income harps on the need to jointly tackle the social, economic, environmental, institutional as well as technological issues as they relate to housing. This will certainly enhance the housing quality of the low-income earners and by extension, improve their quality of life 
as well as their wellbeing. Therefore, rigorous awareness of the concept has to be embarked upon by the government as well as stakeholders in the Nigerian housing industry by exposing the benefits of the concept with respect to low-income housing to the public. The concerned authorities in Nigeria must as a matter of urgency stimulate and encourage sustainable affordable practices in future lowincome housing interventions.

Furthermore, this study gleaned sustainable affordable housing components as well as strategies from literature. Similarly, sustainable affordable housing strategies through which low-income housing can be addressed in Nigeria have been presented. However, the need for more researches on the concept in relation to low-income housing cannot be over emphasized. Therefore, future empirical and contextual researches are encouraged to holistically investigate sustainable affordable housing components, indicators as well as strategies in Nigeria. Future researches are equally encouraged in the area of developing a sustainable affordable housing model or framework for the low-income earners in Nigeria as well as other developing nations.

\section{Referencias}

1. Ibem, E. \& Aduwo, E. (2015). "A Framework for understanding Sustainable Housing for Policy Development and practical actions," in ARCHITECTS COLLOQUIUM, Abuja, Nigeria.

2. Smith, S. (2012). "International Encyclopedia on Housing and Home," Elsevier.

3. Hamnett, C. \& Ward, P. (2012). "Welfare and Well-being. In S.J. Smith (Ed.), International Encyclopedia of Housing and Home," Elsevier.

4. Hamman, S. (2015). "Housing matters. In E. Glaeser, \& Joshi-Ghani (Eds.). The Urban Imperative: Towards competitive cities," Oxford University Press, Oxford.

5. Amoatey, C., Ameyaw, Y., Adaku, E. \& Famiyeh, S. (2015). "Analysing delay causes and effects in Ghanaian state housing construction projects"," International Journal of Managing Projects in Business,, vol. 8, no. 1, pp. 198-214.

6. Glaeser, E. \& Joshi-Ghani, A. (2014). "Rethinking cities: Towards shared prosperity. Economic Premise 126.," The World Bank, Washington.

7. Collier, P. \& Venables, A. (2015). "Housing and Urbanisation in Africa: unleashing a formal market process. In E. Glaeser, \& A. Joshi-Ghani (Eds), The urban imperatice: Towards competitive cities," Oxford University Press, Oxford, 2015.

8. Syed Jamaludin, S., Mahayuddin, S. \& Hamid, S. (2018). "Challenges of Integrating Affordable and Sustainable Housing in Malaysia," in IOP Conference Series: Earth and Environmental Science, 2018.

9. Un-Habitat, (2013). "Planning and Design for Sustainable Urban Mobility: Global report on Human Settlements 2013," Routledge, Abingdon.

10.Cahf (2018). Centre for Affordable Housing Finance, Africa, "Housing Finance in Nigeria," http://housingfinanceafrica.org/countries/nigeria/.

11.Adabre, M. \& Chan, A. (2019). "Critical Success Factors (CSFs) for Sustainable Affordable Housing," Building and Environment, vol. 156, pp. 203-214.

12.Igwe, P., Okeke, C., Onwurah, K., Nwafor, D. \& Umeh, C. (2017). "A Review of Housing Problems," International Journal of Environment, Agriculture and Biotechnology, vol. 2, no. 6, pp. 3092-3099.

13.Rigon, A. (2016). "Collective or individual tiles? Conflict over tenure regularisation in a Kenya Informal Settlement," Urban Studies, vol. 53, no. 1, pp. 2758-2778.

14.Sachs, J. (2015). "The Age of Sustainable Development: Sustainable Development as an Analytical and Normative Concept," The European Policy Review.

15.Gilbert, A. (2014). "'Free housing for the poor: an alternative way to address poverty"," Habitat International, vol. 41, pp. 253-261.

16.Golubchikov, O. \& Badyina, A. (2012). "Sustainable Housing for Sustainable Cities: A Policy Framework for Developing Countries," UN-HABITAT, Nairobi, Kenya.

17.Bons, O., Onochie, A. \& Nzewi, N. (2019). "Where is Home for the Abuja, Nigeria Urban Poor?," Intl. J. Trend. Sci. Res. Dev., vol. 3, pp. 45-56. 
18.Oni-Jimoh, T. \& Liyanage, C. (2018). "Urbanization and Meeting the Need for Affordable Housing in Nigeria," IntechOpen, pp. 73-91.

19.Okafor, B. (2016). "The Residential Housing Problem in Anambra State (A Case Study of Onitsha Metropolis)," International Journal of Civil Engineering, Construction and Estate Management, vol. 4, no. 2, pp. 1-18.

20.Ismail, M., Ezra, I., Abdulkadir, M., Muhammed, A. \& Hadiza, T. (2015). "Urban Growth and Housing Problems in Karu," Global Journal of Research and Review, vol. 2, no. 1, pp. 1-13.

21.Ugochukwu, I.B., \& Chioma, I. (2015). "Local Building Materials: affordable strategy for housing the Urban poor in Nigeria.," Procedia Engineering, vol. 118, pp. 42-49.

22.Iheme, J., Effiong, J. \& Ekung, S. (2015). "The Effect of Government Policy on Housing Delivery in Nigeria: A Case Study of Port Harcourt Low Income Housing Programme," Journal of International Letters of Social and Humanistic Sciences, vol. 61, pp. 87-98.

23.Olotuah, A. \& Taiwo, A. (2015). "Housing Strategies and Quality of Housing in Nigeria: what lessons from Wales?," Developing Country Studies, vol. 5, no. 16, pp. 1-7.

24.Muhammad, Z., Johar, F., Sabri, S. \& Jonathan, Z. (2015). "A Review of Housing Provision and the Challenges of Sustainable Housing Delivery in the Federal Capital Territory Abuja, Nigeria.," Jurnal Teknologi, vol. 77, no. 14, pp. 23-31.

25.FGN (2012). Federal Government of Nigeria, "National Housing Policy," Federal Ministry of Lands, Housing and Urban Development, Abuja.

26.Ocholi, S., Manase, D., Lowe, J. \& Sonnerville, J. (2015). "Critical Review of Nigerian National Housing Policies Delivery (NNHPD)," International Journal of Engineering Research \& Technology, vol. 4, no. 9, pp. 718-724.

27.Afolabi, A., Akinbo, F. \& Akinola, A. (2019). "Vertical Architecture Construction: Prospects and Barriers in solving Lagos' Housing Deficit," Journal of Physics: Conference Series, pp. 1-6.

28.Friesen, J., Tuabenbock, H., Wurm, M. \& Pelz, F. (2018). "The Similar Size of Slums," Habitat International, vol. 73, pp. 79-88.

29.Yuan, J., Li, W., Zheng, X. \& Skibniewski, M. (2018). "Improving Operations Performance of Public Rental Housing Delivery by PPPs in China," Journal of Management Engineering, vol. 34, no. 4.

30.Turok, I. (2016). "Housing and the Urban Premium," Habitat International, vol. 54, pp. 234-240.

31.Mulliner, E., Smallbone, K. \& Maliene, V. (2013). "An Assessment of Sustainable Housing Affordability Using a Multiple Criteria Decision making Method," Omega, vol. 41, no. 2, pp. 270279.

32.Tech-Hong, T. (2012). "Housing Satisfaction in medium and High Cost Housing: the case of Greater Kuala Lumpur, Malaysia," Habitat International, vol. 25, no. 1, pp. 108-116.

33.Adabre, M., Chan, A., Darko, A., Osei-Kyei, R., Abidoye, R. \& Adjei-Kumi, T. (2020). "Critical Barriers to Sustainability Attainment in Affordable Housing: International Construction Professionals' Perspective," Journal of Cleaner Production, pp. 1-18.

34.Ezennia, I. \& Hoskara, I. (2019). "Methological weaknesses in the measurement approaches and concept of housing affordability used in housing research: A qualitative study," PLoS ONE, vol. 14, p. 221246.

35.Ghazali, E., Ngiam, E. \& Mutum, D. (2019). "Elucidating the Drivers of Residential Mobility and Housing Choice Behaviour in a Suburban Township via push-pull-mooring Framework," J. Hous. Built Environ., pp. 1-27.

36.Chan, A. \& Adabre, M. (2019). "Bridging the gap between Sustainable Housing and Affordable Housing: The required critical success criteria (CSC)," Build. Environ., vol. 151, pp. 112-125.

37.Vehbi, B., Hoskara, E. \& Hoskara, S. (2010). "A Theoretical Approach for Assessing Sustainability in Housing Environment," Open House Int., vol. 35, pp. 26-36.

38.Olanrewaju, A., Tan, S. \& Abdul-Aziz, A. (2018). "Housing providers' insights on the benefits of sustainable affordable housing," Sustainable Development, vol. 26, pp. 847-858.

39. Wittemore, R., Knafl, K. \& Gray, E. (2005). "The Integrative Review: Updated Methodology," Journal of Advanced Nursing, vol. 52, no. 5, pp. 546-553. 
40.Green, S. (2005). "Syatematic Review and Meta-analysis," Singapore Medical Journal, vol. 46, no. 6, pp. 270-274.

41.Aduwo, E., Edewor, P. Ibem, E. (2016). "Urbanization and Housing for Low-Income Earners in Nigeria: A Review of Features, Challenges and Prospects," Mediterranean Journal of Social Sciences, vol. 7, no. 3, pp. 347-357.

42.Khnan, K., Kunz, R., Kleijnen, J. \& Antes, G. (2003). "Five Steps to Conducting a Systematic Review," Journal of Royal Society of Medicine, vol. 96, pp. 118-121.

43.Falagas, M., Pitsouni, E., Malietzis, G. \& Pappas, G. (2008)."Comparison of PubMed, Scopus, Web of Science and Google Scholar: Strengths and Weaknesses," FASEB Journal, vol. 22, pp. 338342.

44.WCED (1987). "Our Common Future. A Report of the World Commission on Environment and Development," Oxford University Press, Oxford.

45.Ibem, E. \& Azuh, D. (2011). "Framework for Evaluating the Sustainability of Public Housing

46.Programmes in Developing Countries," Journal of Sustainable Development and Environmental Protection (JSDEP), vol. 1, no. 3, pp. 24-39.

47.Lee, E. \& Park, N. (2010). "Housing Satisfaction and Quality of Life among Temporary Residents in the United States," Housing and Society, vol. 37, no. 1, pp. 43-67.

48.Dryzek, J. (1997). Democracy in Capitalist Times: Ideals. Limits and Struggles. OUP Catalogue, Oxford University Press.

49.Porter \& Brown, (1996). Global Environmental Politics, 2nd ed., Boulder, Colorado: Westview Press.

50.Weale, A. (1992). The New Politics of Pollution, Oxford, United Kingdom: Manchester University Press.

51.Sandbach, F. (1980). Environment, Ideology and Policy, Oxford: Bsail Blackwell.

52.Ibem, E. \& Aduwo, E. (2013). "Assessment of residential satisfaction in public housing in Ogun State, Nigeria," Habitat International, vol. 40, pp. 163-175.

53.Sharifzai, M., Kitagawa, K., Habib, A., Halimee, M. \& Sakaguchi, D. (2016). "Investigation of Sustainable and Affordable Housing Policy Principles and Formulation adoptable in Kabul City, Afghanistan.," Journal of Sustainable Development, vol. 9, no. 2, pp. 93-126.

54.Makinde, O. (2014). "Housing Delivery System, Need and Demand," Environment, Development and Sustainability, vol. 16, no. 1, pp. 49-69.

55.Aribigbola, A. (2011). "Housing Affordability as a Factor in the Creation of Sustainable Environment in Developing World: the example of Akure, Nigeria.," Journal of Human Ecology, vol. 35, no. 2, pp. 121-131.

56.Friedman, R. \& Rosen, G. (2018). "The Challenge of Conceptualizing Affordable Housing: definitions and their underlying agendas in Isreal," Housing Studies, pp. 1-23.

57.Adeogun, O. \& Taiwo, A. (2011). "Housing Delivery through Public- Private Partnership in Nigeria and the case for Beneficiaries' Involvement," Journal of Construction Project Management and Innovation, vol. 1, no. 2, pp. 63-79.

58.Disney, J. (2007). "Affordable Housing in Australia, some key problems and priorities for action, National Forum on Affordable Housing.," Australian Housing and Urban Research Institute, Melbourn.

59.Rowley, S. \& Ong, R. (2012). "Housing Affordability, Housing Stress and Household Wellbeing in Australia. Final Report No.192," Australia Housing and Urban Research Institute, Melbourne, Australia.

60.Chapman, P. (2006). Housing Affordability in Australia.

61.Nwaba, C. \& Kalu, I. (2018). "Measuring Housing Affordability: The two approaches," ATBU Journal of Environmental Technology, vol. 11, pp. 127-143.

62.Mulliner, E., Malys, N. \& Maliene, V. (2016). "Comparative Analysis of MCDM Methods for the Assessment of Sustainable Housing Affordability," Omega, vol. 59, pp. 146-156.

63.Leishman, C. \& Rowley, S. (2012). Affordable Housing. In The Sage Handbook of Housing Studies, edited by Clapham, D.F., Clark, W.A.V., and Gibb, K., Los Angeles: Sage.

64.Mulliner, E. \& Maliene, V. (2015). "An Analysis of Professional Perceptions of Criteria Contributing to Sustainable Housing Affordability," Sustainability, vol. 7, no. 1, pp. 248-270. 
65.Isalou, A.A., Litman, T. \& Shahmoradi, B. (2014). "Testing the Housing and Transportation

66.Affordability Index in a Developing World Context: A Sustainability Comparison of Central and Suburban Districts in Qom, Iran," Transport policy. 2014 May 1; 33:33-9., vol. 33, pp. 33-39.

67.Nubi, G. \& Afe, Y. (2014). "Redefining Affordable Housing through Sustainable Practices," http://www.salford.ac.uk/_data/assets/pdf_file/0003/142419/058-Nubi.pdf.

68. Mattingly, K. \& Morrissey, J. (2014). "Housing and Transport Expenditure: Socio-Spatial Indicators of Affordability in Auckland," Cities, vol. 38, p. 69-83.

69.Fisher, L.M., Pollakowski, H. \& Zabel, J. (2009). "Amenity-based housing affordability indexes.," Real Estate Economics, vol. 37, no. 4, p. 705-746.

70.Sullivan, E. \& Ward, P. (2012). "Sustainable Housing Applications and Policies for Low-income Selfbuild and Housing Rehabilitation," Habitat International, vol. 36, no. 2, pp. 312-323.

71.Gan, X., Zuo, J., Wen, T. \& She, Y. (2019). "Exploring the Adequacy of Massive Constructed Public Housing in China," Sustainability, vol. 11, p. 1949.

72. Olanrewaju, A. \& Woon, T. (2017). "An exploration of the determinants of affordable housing choice," International Journal of Housing Market Analysis, vol. 10, pp. 703-723.

73.Ram, P. \& Needham, B. (2016). "The Provision of Affordable Housing in India: are commercial developers interested?," Habitat International, vol. 55, pp. 100-108.

74.Salvi Del Pero, A., Adema, W., Ferraro, V. \& Frey, V. (2016). "Policies to Promote Access to Good Quality Affordable Housing iin OECD Countries (No. 176)," OECD Publishing.

75.Lechtenbohmer, S. \& Schuring, A. (2011). "The Potential for Large-scale Savings from Insulating Residential Buildings in the EU," Energy Efficiency, vol. 4, no. 2, pp. 257-270.

76.Penrose, K., De Castro, M., Werema, J. \& Ryan, E. (2010). "Informal Urban Settlements and Cholera Risks in Dar es Salaam, Tanzania," PLos NeglectedTropical Disease, vol. 4, no. 3.

77.Freeman, L. (2002). "America's Affordable Housing Crisis: A Contract Unfulfilled," American Journal of Public Health, vol. 92, no. 5, pp. 709-712.

78.Abidin, N., Yusuf, N. \& Othman, A. (2013). "Enablers and Challenges of Sustainable Housing Industry in Malaysia," Journal of Construction Innovation, vol. 13, no. 1, pp. 10-25.

79.Boamah, N. (2010). "Housing Affodability in Ghana: A focus on Kumasi and Tamale," Ethiopian Journal of Environmental Studies and Management, vol. 3, no. 3, pp. 1-11.

80.Choi, E. (2020). The Effects of Municipal Policy on Green Building Designations in The United States.

81.Nair, D., Enserink, B., Gopikuttan, G., Vergragt, P., Fraaij, A. \& Dalmeijer, R. (2005). "A Conceptual Framework for Sustainable- Affordable Housing for the Rural Poor in Less Developed Economies," in World Sustainable Building Conference, Tokyo.

82.Trudeau, D. (2018). "Integrating Social Equity in Sustainable Development Practice: Institutional Commitments and Patient Capital," Sustainable Cities Society, vol. 41, pp. 601-610.

83.Tan, Y., Liu, G., Zhang, Y., Shuai, C. \& Shen, G. (2018). "Green retrofit of aged residential building in Hong Kong: a preliminary study," Building and Environment, vol. 143, pp. 89-98.

84.Dubose, J., Bosch, S. \& Pearce, A. (2007). "Analysis of state-wide green building policies," J. Green Build., vol. 2, no. 2, pp. 161-177.

85.Kwofie, T., Afram, S. \& Botchway, E. (2016). "A Critical Success Model for PPP Public Housing Delivery in Ghana," Built Environment Project and Asset Management, vol. 6, no. 1, pp. 58-73.

86.Abdul-Aziz, A. \& Kassim, P. (2011). "Objectives, success and failure factors of housing public-private partnerships in Malaysia," Habitat International, vol. 35, no. 1, pp. 150-157.

87.Ganiyu, B., Fapohunda, J. \& Haldenwang, R. (2017). "Sustainable housing financing model toreduce South Africa housing deficit," Internation Journal of Housing Market Analysis, vol. 10, no. 3, pp. 410430.

88.Chan, A., Darko, A. \& Ameyaw, E. (2017). "Strategies for promoting green building technologies adoption in the Construction Industry-an International Study," Sustainability, vol. 9, no. 6, p. 969.

89.Sadineni, S., Madala, S. \& Boehm, R. (2011). "Passive building energy savings: a review of building envelop components," Renew. Sustain. Energy Rev., vol. 15, no. 8, pp. 3617-3631.

90.Roufechaei, K., Bakar, A. \& Tabassi, A. (2014). "Energy-efficient design for sustainable housing development," J. Cleanear. Production, vol. 65, no. 15, pp. 380-388. 
91.Ross, N., Bowen, P. \& Lincoln, D. (2010). "Sustainable housing for low-income communities:lessons for South Africa in local and other developing world cases," Construction Management Economics, vol. 28 , no. 5, pp. 433-449.

92.Mondal, B. \& Das, D. (2018). "Hoe residential compactness and attractiveness can be shaped by environmental amenities in an Industrial City," Sustainable Cities and Society, vol. 41, pp. 363-377. 91. DEMPSEY, N., BROWN, C. \& BRAMLEY, G. (2012). "The key to sustainable urban development in UK Cities? The influence of density on social sustainability," Progect Planning, vol. 77, no. 3, pp. 89141.

93.SCGO (2013). "The Technical Guidelines of Green Affordable Housing," Beijing China.

94.Charoenkit, S. \& Kumar, S. (2014). "Environmental sustainability assessment tools for low carbon and climate resilient low income housing settlements," Renewable Sustainable Energy Review, vol. 38, pp. 509-525.

95.Czischke, D. \& Van Bortel, G. (2018). "An exploration of concepts and policies on Affordable Housing in England, Italy, Poland and Netherlands.," Journal of Housing and Built Environment, pp. https://doi.org/10.1007/s10901-018-9598-1.

96.Ogunsanmi, O. (2013). "Stakeholders' perception of key performance indicators (KPIs) of publicprivate partnership (PPP) projects," International Journal of Construction Supply Chain Management, vol. 3, no. 2, pp. 27-38.

97.Agyemang, F. \& Morrison, N. (2018). "Recognising the barriers of securing affordable housing through the land use planning system in Sub-Sahara Africa: a perspective from Ghana," Urban Studies, vol. 55, no. 12 , pp. 2640-2659.

98.Obeng-Odoom, F. (2010). "An Urban Twist to Politics in Ghana," Habitat International, vol. 34, no. 4, pp. 392-399.

99.Alam, Y., Zuo, P., Stewart, R., Bertone, E., Sahin, O., Buntine, C. \& Marshall, C. (2019). "Government Championed Strategies to overcome the Barriers to Public Building Energy Efficiency Retrofit Projects," Sustainable Cities and Society, vol. 44, pp. 56-69.

100. Sulemana, I., Nketiah-Amponsah, E., Codjoe, E. \& Andoh, J. (2019). "Urbanization and income inequality in Sub-Sahara Africa," Sustainable Cities Society, vol. 48, p. 101544.

101. Massey, D., Rothwell, J. \& Domina, T. (2009). "The changing bases of segregation in the United States," The Annala of the American Academy of Political and Social Science, vol. 626, no. 1, pp. 7490, 2009.

102. Gianfrate, V., Piccardo, C.L.D. \& Giachetta, A. (2017). "Rethinking social housing: behavioural patterns and technological innovations," Sustain. Cities Soc., vol. 33, pp. 102-112.

103. Gooding, T. (2016). "Low-income housing provision in Mauritius: improving social justice and place quality," Habitat International, vol. 53, pp. 502-516.

104. Twumasi-Ampofo, K., Osei-Tutu, E., Decardi-Nelson, I. \& Ofori, P. (2014). "A Model for Reactivating Abandoned Public Housing Projects in Ghana," Civil and Engineering Research, vol. 6, no. 3, pp. 6-16.

105. Power, A. (2008). "Does Demolition or Refurbishment of old and Inefficient Homes helps to increase our Environment, Social and Economic Viability?," Energy Policy, vol. 36, pp. 4487-4501.

106. Murphy, L. (2016). "The politics of land supply and affordable housing: Auckland's Housing Accord and Special Housing Areas," Urban Studies, vol. 53, no. 12, pp. 2530-2547.

107. Chan, A., Darko, A., Olanipekun, A. \& Ameyaw, E. (2018). "Critical Barriers to Green Building Technologies Adoption in Developing Countries: the case of Ghana.," Journal of Cleaner Production, vol. 172, pp. 1067-1079.

108. Garde, A. (2016). "Affordable by design? Inclusionary housing insights from Southern California," J. Plan. Edu. Res., vol. 36, no. 1, pp. 16-31.

109. Onu, V. \& Onu, A. (2012). "Urban Resudential Housing and Low-income Earners: A study of Makurdi Metropolis, Benue State, Nigeria," European Scientific Journal, vol. 28, pp. 231-246.

110. Taylor, J. (2011). "Sustainable Building Practices: Legislative and Economic Incentives. Management and Innovation for a Sustainable Built Environment (MISBE)," Association of European Schools of Planning, Dortmond, Germany. 
111. Perez-Lombard, L., Ortiz, J. \& Pout, C. (2008). "A review on buildings energy consumption information," Energy and Buildings, vol. 40, no. 3, pp. 394-398.

112. Pearce, A. \& Ahn, Y.H. (2013). Sustainable buildings and infrastructure: Paths to the future, Routledge.

113. Nielsen, A.N., Jensen, R.L., Larsen, T.S. \& Nissen, S.B. (2016). "Early stage decision support for sustainable building renovation-A review," Building and Environment, vol. 103, pp. 165-181.

114. Nelms, G., Russell, A. \& Lence, B. (2005). "Assessing the performance of sustainable technologies for building projects," Can. J. Civ. Eng., vol. 32, no. 1, pp. 114-128.

115. Huang, J., Shen, G. \& Zheng, H. (2015). "Is Insufficient Land Supply the Root cause of Housing Shortage? Empirical evidence fron Hong Kong," Habitat International, vol. 49, pp. 538-546.

116. Ebekozien, A., Abdul-Aziz, A. \& Jaafar, M. (2019). "Housing finance inaccessibility for lowincome earners in Malaysia: Factors and solutions," Habitat International, vol. 87, pp. 27-35.

117. Roumboutsos, A. \& Macário, R. (2013). "Public private partnerships in transport: theory and practice," Built Environment Project and Asset Management, vol. 3, no. 2, pp. 160-164.

118. Tang, L., Shen, Q. \& Cheng, E. (2010). "A review of studies on public - private partnership projects in the construction industry," International Journal of Project, vol. 28, no. 7, pp. 683-694.

119. Adegun, O., Joseph, A. \& Adebusuyi, A. (2019). "Housing Affordability among Low-Income Earners in Akure, Nigeria," in Material Science and Engineering.

120. Ezeigwe, P. (2015). "Evaluation of the Causes of Housing Problems in Nigeria: A Case Study of Awka the Capital City of Anambra State.," Journal of Economics and Sustainable Development, vol. 6, no. 20, pp. 1-7.

121. Ugonabo, C. \& Emoh, F. (2013). "The Major Challenges to Housing Development and Delivery in Anambra State of Nigeria," Civil and Engineering Research, vol. 3, no. 4, pp. 1-19.

122. Goh, K., Seow, T. \& Goh, H. (2015). "Challenges of Implementing Sustainability in Malaysian Housing Industry,".

123. Saleh, M. \& Alalouch, C. (2015). "Towards sustainable construction in Oman: Challenges \& opportunities," Proceedia Engineering, vol. 118, pp. 177-184.

124. Ankeli, I., Dabara, I., Omotehinse, J., Lawal, O., Odeyomi, F. \& Adebowale, A. (2017). "Affordable and Acceptable Mass Housing Delivery: A Panacea to the Nigeria Housing Problem," Conference of International Journal of Art \& Sciences, vol. 10, no. 01, pp. 31-38.

125. Un-Habitat (2012). "Sustainable Housing for Sustainable Cities: A Policy Framework for Developing Countries," UN-HABITAT, Nairobi, Kenya.

126. Kotkin, J. (2013). "American Emerging Housing Crisis," American Works. Assessed ar:

127. http://www.forbes.com/joelkotkin/2013/07/26/Americas-emerging-housing-crisis.

128. Qureshi, Muhammad Imran, et al. "Classifications of sustainable manufacturing practices in ASEAN region: A systematic review and bibliometric analysis of the past decade of research." Sustainability 12.21 (2020): 8950. 